\title{
Effect of Mucuna Pruriens Seeds Supplementation on Heat Shock Proteins and Mitochondrial Gene Expression in Beetal Goats in Relation to Seasonal Stress
}

Sameer Niwas Jadhav ( $\nabla$ sameerbiochem@gmail.com )

Guru Angad Dev Veterinary and Animal Sciences University https://orcid.org/0000-0002-8595-4449

Shashi Nayyar

Guru Angad Dev Veterinary and Animal Sciences University

Chanchal Singh

Guru Angad Dev Veterinary and Animal Sciences University

C.S Mukhopaddhyay

Guru Angad Dev Veterinary and Animal Sciences University

B.V. Sunil Kumar

Guru Angad Dev Veterinary and Animal Sciences University

\section{Research Article}

Keywords:

Posted Date: January 27th, 2022

DOI: https://doi.org/10.21203/rs.3.rs-1167206/v1

License: (c) (1) This work is licensed under a Creative Commons Attribution 4.0 International License.

Read Full License 


\section{Abstract}

Mucuna pruriens seeds are known to exhibit antistress and antioxidant properties. The study was conducted to analyze the effect of Mucuna pruriens seed supplementation on heat shock protein (HSP) and mitochondrial gene expression, which are considered as molecular markers of heat stress. Adult beetal does, and kids were given $100 \mathrm{mg} / \mathrm{kg}$ bodyweight of $M$. pruriens seed powder for 30 days during the winter and summer seasons. Gene expression of HSP-70, HSP-90 genes, and mitochondrial cytochrome $B$ and cytochrome oxidase subunit I gene were tested on day 0 and day 30 blood samples. Average THI was significantly higher during summer, while relative humidity remained significantly higher during the winter season. HSP-70 and HSP-90 gene expression were found to be significantly decreased while COX-I and CYT B were found significantly increased in Mucuna pruriens supplemented does and kids during both summer and winter season compared to the control group. Supplementing Mucuna pruriens seeds @ $100 \mathrm{mg} / \mathrm{kg}$ body weight to goats leads to a decrease in thermal stress response and increases mitochondrial respiration efficiency as evident from increase in mitochondrial gene expression, thus ameliorating seasonal stress response and improving the overall physiological adaptability of the goat to seasonal stress.

\section{Introduction}

M.pruriens is a leguminous plant having rich nutritional and phytochemical content. The most available literature of $M$. pruriens in animals cites the use of processed M.pruriens seeds as unconventional feedstuffs to utilize their nutrient content only. Various phyto-constituents in M.pruriens seeds include alkaloids, tri-terpenes, glycosides, tannins, phytosterols, flavonoids, and phenolic \& polyphenolic compounds exhibiting varied physiological and pharmacological activities. Several Scientific studies in humans and laboratory animals have demonstrated the herbal supplement potential of raw powdered $M$. Pruriens seeds in terms of antioxidant, antistress, anti-cholestrolemic, anti-diabetic, fertility-enhancing, anti-inflammatory, and anti-microbial properties (Misra and Wagner, 2007). Microarray and real-time PCR gene expression analysis of $M$. Pruriens extract treatment versus the control group in rat heart showed that 59 genes are differentially expressed, which includes gene related to inflammatory, immune response, energy metabolism, apoptosis, eicosanoid synthesis, blood and wounding response, cardiac muscle and nervous system having a protective effect on the heart (Fung et al. 2014). Thus M.pruriens seeds exhibit nutraceutical potential in terms of delivering both nutritional and health benefits to the animals. Still, no extensive molecular studies have been done in animals to evaluate the antistress potential of seeds in terms of their effect on thermotolerance level, oxidative stress-related mitochondrial functional response.

Heat shock proteins (HSPs) are multigene family proteins that range in molecular size from 10- $150 \mathrm{kda}$ found in all major cellular compartments. Heat shock proteins (HSPs) are considered as markers of thermotolerance of animals. They are a highly conserved proteins that are ubiquitously expressed in an animal's body during thermal stress. Out of all the members present in this family, HSP-70 is regarded as the most significant indicator of thermal stress. HSP-70 is known to be a highly inducible chaperon and 
plays a key role in stabilizing the native conformation of proteins and maintenance of cell survivability during thermal stress (Beckham et al., 2004). The expression of HSP-70 genes (HSPA8, HSPA6, HSPA1A, HSPA1L, and HSPA2) showed temperature sensitivity and seasonal variation. Relative expression of HSP70 genes varied markedly among the heat- and cold-adapted goat breeds with a moderate variation between breeds and showed a good response to increased or decreased ambient temperature (Banerjee et al., 2014). The heat-shock protein (HSP) 90 belongs to the molecular chaperones class that participates in the normal folding, intracellular localization and proteolytic turnover of several proteins, including key regulators of cell growth and survival (Prodrumou and Pearl 2003). Two major cytoplasmic forms, $a$ (inducible) and $\beta$ (constitutive), of the protein, are recognized. Owing to its inducible expression, HSP-90a form exerts a relevant role in cell homeostatic responses to stressful conditions. Singh et al. (2017) reported that the expressions of HSP-70 and HSP-90 were increased significantly in goats that were subjected to heat stress.

Mitochondrial functional status is found to be an important marker in determining adaptive cellular response to heat stress. Mitochondrial DNA is highly sensitive to oxidative stress (Yakes and Van Houten 1997, Barja and Herrero 2000). Mitochondria are the main source as well as the target of free radicals. Heat stress stimulates the excessive production of free radicals (Bernabucci et al.,2002). Mitochondrial DNA lacks histones and other DNA-associated proteins, making it readily accessible to oxidative damage. Further mitochondrial DNA is near the ETC where ROS production occurs. Therefore they are an easy target for ROS-induced damage (Kakkar and Singh, 2007). Altered mitochondrial gene expression activates cytochrome $\mathrm{c}$ mediated intrinsic cellular apoptotic pathway. An increase in caspase 3 activity was found in mice repeatedly exposed to thermal stress (Kim et al., 2013). Relative gene expression of mitochondrial genes was lowered in karan fries bulls subjected to heat stress in tropical climates (Soren et al., 2018).

Considering the importance of HSP and mitochondrial gene in thermal stress response, research work was carried out to study the effect of M.prurien supplementation on the relative expression of heat shock proteins, and mitochondrial gene in beetal does and goat kids during winter and summer season.

\section{Material And Method}

Sixteen adult beetal does and goat kids were separately and randomly assigned to one of two groups: control or M.pruriens supplemented (8 goats in each group). Experiment was carried out during two seasons viz the winter (December-January month) and summer seasons (May-June) on separate goats. Adult does, and goat kids in the treatment groups were fed a standard diet plus $100 \mathrm{mg} / \mathrm{kg}$ body weight of raw M. Pruriens powdered seeds /animal/ (dose as per Doromala et al 2015) for 30 days. Control goats were fed with only basal diet as per NRC recommendations. Environmental parameters viz temperature, relative humidity was recorded. THI was calculated as per Tucker et al. (2008). Gene expression studies for the following genes were carried out before $M$. pruriens supplementation (0th day) and after M. pruriens supplementation (on 30th day) on blood samples in does and kids during winter \& summer Season. 
- Heat stress Markers- HSP-70 and HSP-90.

- Mitochondrial functional stress markers-Cytochrome b (CYT-B) and Cytochrome oxidase subunit-I $(\mathrm{COX}-\mathrm{I})$

Gene-specific primers were designed using online Genescript real-time PCR primer design software available online, and the specificity was checked using NCBI BLAST (http://www.ncbi.nlm.nih.gov/tools/primer-blast/). The details of primer are described in Table 1.

Table 1

Primer sequence of target genes

\begin{tabular}{|c|c|c|c|c|c|}
\hline $\begin{array}{l}\text { Sr. } \\
\text { No }\end{array}$ & Gene & F/R & Sequence & Product size & $\begin{array}{l}\text { Reference } \\
\text { Accession No }\end{array}$ \\
\hline \multirow[t]{2}{*}{ 1) } & \multirow{2}{*}{$\begin{array}{l}\text { HSP-70 } \\
\text { (HSP70.3) }\end{array}$} & Forward & TCATCGGAGATGCAGCCAAGAA & \multirow[t]{2}{*}{210} & \multirow[t]{2}{*}{ JN833720.1 } \\
\hline & & Reverse & AGATCTCCTCGGGGAAGAAGGT & & \\
\hline \multirow[t]{2}{*}{ 2) } & \multirow{2}{*}{$\begin{array}{l}\text { HSP-90 } \\
\text { (HSP90AA1) }\end{array}$} & Forward & TCTGATGACAAGCCCGAGAT & \multirow[t]{2}{*}{145} & \multirow[t]{2}{*}{ AF548366.1 } \\
\hline & & Reverse & TGGTCCAGATAGGCTTCGTC & & \\
\hline \multirow[t]{2}{*}{ 3) } & \multirow[t]{2}{*}{ Cyt-B } & Forward & ATATTCCGCCCAATCAGCCA & \multirow[t]{2}{*}{169} & \multirow[t]{2}{*}{ MK341077.1 } \\
\hline & & Reverse & TGGTGCTAGCTGCTGGTATT & & \\
\hline \multirow[t]{2}{*}{ 4) } & \multirow[t]{2}{*}{ Cox-I } & Forward & GGCACСCTCTACCTTCTGTT & \multirow[t]{2}{*}{148} & \multirow[t]{2}{*}{ MK341077.1 } \\
\hline & & Reverse & TTACGAATGCGTGTGCAGTT & & \\
\hline \multirow[t]{2}{*}{ 5) } & \multirow[t]{2}{*}{ GADPH } & Forward & GCAAGTTCCACGGCACAG & \multirow[t]{2}{*}{118} & \multirow[t]{2}{*}{ AJ431207 } \\
\hline & & Reverse & TCAGCACCAGCATCACCC & & \\
\hline
\end{tabular}

Total RNA from the blood samples was extracted using trizol method. The total RNA concentration was determined, and purity was checked using the nanodrop spectrophotometer reading. OD 260/OD 280 value calculated for possible RNA contamination with protein or DNA.. The constant amount $(6 \mu \mathrm{g})$ of isolated total RNA is reverse transcribed using cDNA Synthesis Kit (Puregene). The resulting cDNA was used in quantitative RT-PCR reactions. SYBR green chemistry was used to analyze relative gene expression. The glyceraldehyde 3-phosphate dehydrogenase (GAPDH) gene was used as an internal control. Each sample was run in duplicate for the target \& reference control gene. No template control (NTC) was put for gene quantification for checking the contamination in the reaction component other than the cDNA. The melt curve analysis was done to check the non-specific amplification. The real-time qPCR reaction conditions were: 


\begin{tabular}{|c|c|c|c|c|}
\hline Segment & Remark & Thermal Profile & Time & No of cycles \\
\hline 1 & Hot start PCR & $95^{\circ} \mathrm{C}$ & $15 \mathrm{~min}$ & 1 \\
\hline \multirow[t]{3}{*}{2} & Denaturation & $95^{\circ} \mathrm{C}$ & $10 \mathrm{sec}$ & \multirow[t]{3}{*}{35} \\
\hline & Annealing & $58^{\circ} \mathrm{C}$ & $30 \mathrm{Sec}$ & \\
\hline & Extension & $72^{\circ} \mathrm{C}$ & $30 \mathrm{sec}$ & \\
\hline \multirow[t]{4}{*}{3} & \multirow[t]{4}{*}{ Dissociation curve analysis } & $95^{\circ} \mathrm{C}$ & $1 \mathrm{~min}$ & \multirow[t]{4}{*}{1} \\
\hline & & $65^{\circ} \mathrm{C}$ & $30 \mathrm{sec}$ & \\
\hline & & $65^{\circ} \mathrm{C}-95^{\circ} \mathrm{C}$ & 2 degree per min & \\
\hline & & $95^{\circ} \mathrm{C}$ & $30 \mathrm{sec}$ & \\
\hline
\end{tabular}

After the run has ended, cycle threshold (Ct) values and amplification plot for all determined. Mean $\Delta \mathrm{Ct}$ of each target gene with reference to internal control was calculated. The relative gene expression change were expressed as fold change $\left(2^{\wedge}-\Delta \Delta \mathrm{Ct}\right)$. log2 fold change value was calculated for symmetrical analysis. Data was analyzed to identify following three main effects.

\section{Mean $\Delta \Delta C t$ comparison for relative gene expression}
1) Mean $\Delta \Delta$ Ct of 0 th day relative to 30th days in control and $M$. pruriens supplemented group.
2) Mean $\Delta \Delta \mathrm{Ct}$ in M.pruriens supplemented group relative to control compared on 30th day during winter and summer season.
Effect of M.pruriens supplementation on target gene expression compared to control.
Seasonal difference in the extent of gene expression change in $M$. pruriens supplemented group relative to control
3) Mean $\Delta \Delta \mathrm{Ct}$ in M.pruriens supplemented group relative to control compared on 30th day in does and goat kids.
Difference between does, and kids on the extent of gene expression change in $M$. pruriens supplemented group relative to control

The statistical significance of differences in mRNA expressions of the examined factors was assessed by nonparametric Wilcoxon- Mann-Whitney $U$ test with critical alpha level 0.05 was used for statistical significance using SPSS statistical tool.

\section{Results And Discussion}

\section{Environmental parameters}

Average Temperature $\left({ }^{0} \mathrm{C}\right)$, relative humidity $\% \& \mathrm{THI}$ recorded during the study period were ranged from $12.91 \pm 0.26,78.66 \pm 1.28,55.60 \pm 0.43$ during the winter season and $37.10 \pm 0.68,29.83 \pm 1.39,83.08 \pm 0.35$ during the summer season, respectively. A climatic environment having an air temperature in the range of 
13- $27^{\circ} \mathrm{C}$, relative humidity of $60-70 \%$, THI of less than $65 \%$ (Misra and Puneet,2009) is considered as a comfort zone. During summer and winter, animals were found exposed to an ambient temperature or humidity beyond their comfort zone, which indicates that they were experiencing thermal stress in both seasons while pronounced stress exhibited by animals during the summer season.

\section{Gene expression study}

Agarose gel electrophoresis of PCR product was used to confirm the size of the specific size of amplified PCR product using $100 \mathrm{bp}$ DNA ladder (shown in Fig. 1). All the five genes tested using PCR were shown the expected size of PCR product length. Melt curve analysis conducted after real-time PCR amplification run revealed a single melt peak in all tested target genes (Shown in Fig. 2).

\section{Effect of M. pruriens Supplementation on HSP and Mitochondrial gene expression on $\mathbf{3 0}$ day relative to} day 0

Relative gene expression change in the control and treatment group on 30th day (post feeding) compared to prefeeding ( 0 day) has been represented in table no 2 . $\log _{2}$ gene expression of all tested target genes has been graphically represented in Fig. 3. HSP-70 and HSP-90 gene expression were found to be significantly decreased in $M$. pruriens supplemented does and kids during both summer and winter seasons compared to the control group. 
Table 2

Fold expression and Log2 fold expression of target gene on 30th day(post-feeding) relative to 0th day (prefeeding)

\begin{tabular}{|c|c|c|c|c|c|c|}
\hline Gene & Animal & Season & Group & $\begin{array}{l}\log 2 \text { fold } \\
\log _{2}\left(2^{\wedge} \Delta \Delta c t\right) \\
\text { relative to } \\
\text { day } 0\end{array}$ & $\begin{array}{l}\text { Fold } \\
\text { expression } \\
\left(2^{\wedge}-\Delta \Delta \text { ct) }\right. \\
\text { relative to } 0 \\
\text { day }\end{array}$ & $\begin{array}{l}\text { Gene expression fold } \\
\text { difference ratio }\end{array}$ \\
\hline \multirow{8}{*}{$\begin{array}{l}\text { HSP- } \\
70\end{array}$} & \multirow{4}{*}{$\begin{array}{l}\text { Adult } \\
\text { Doe }\end{array}$} & \multirow[t]{2}{*}{ Winter } & Control & $1.18 \pm 0.18$ & $2.40 \pm 0.30$ & \multirow[t]{2}{*}{6.6} \\
\hline & & & Treatment & $-1.76 \pm 0.37$ & $0.36 \pm 0.08$ & \\
\hline & & \multirow[t]{2}{*}{ Summer } & Control & $1.82 \pm 0.16$ & $3.72 \pm 0.50$ & \multirow[t]{2}{*}{2.58} \\
\hline & & & Treatment & $0.48 \pm 0.13$ & $1.44 \pm 0.12$ & \\
\hline & \multirow{4}{*}{$\begin{array}{l}\text { Goat } \\
\text { Kid }\end{array}$} & \multirow[t]{2}{*}{ Winter } & Control & $1.23 \pm 0.26$ & $2.65 \pm 0.48$ & \multirow[t]{2}{*}{8.54} \\
\hline & & & Treatment & $-1.73 \pm 0.16$ & $0.31 \pm 0.039$ & \\
\hline & & \multirow[t]{2}{*}{ Summer } & Control & $2.03 \pm 0.26$ & $4.55 \pm 0.76$ & \multirow[t]{2}{*}{5.17} \\
\hline & & & Treatment & $-0.40 \pm 0.35$ & $0.88 \pm 0.14$ & \\
\hline \multirow{8}{*}{$\begin{array}{l}\text { HSP- } \\
90\end{array}$} & \multirow{4}{*}{$\begin{array}{l}\text { Adult } \\
\text { Doe }\end{array}$} & \multirow[t]{2}{*}{ Winter } & Control & $0.91 \pm 0.14$ & $1.95 \pm 0.18$ & \multirow[t]{2}{*}{2.43} \\
\hline & & & Treatment & $-0.97 \pm 0.61$ & $0.80 \pm 0.21$ & \\
\hline & & \multirow[t]{2}{*}{ Summer } & Control & $1.91 \pm 0.19$ & $4.01 \pm 0.54$ & \multirow[t]{2}{*}{6.46} \\
\hline & & & Treatment & $-1.31 \pm 0.52$ & $0.62 \pm 0.21$ & \\
\hline & \multirow{4}{*}{$\begin{array}{l}\text { Goat } \\
\text { Kid }\end{array}$} & \multirow[t]{2}{*}{ Winter } & Control & $1.43 \pm 0.26$ & $3.03 \pm 0.54$ & \multirow[t]{2}{*}{2.36} \\
\hline & & & Treatment & $0.19 \pm 0.28$ & $1.28 \pm 0.20$ & \\
\hline & & \multirow[t]{2}{*}{ Summer } & Control & $2.37 \pm 0.16$ & $5.45 \pm 0.58$ & \multirow[t]{2}{*}{6.81} \\
\hline & & & Treatment & $-0.50 \pm 0.27$ & $0.80 \pm 0.15$ & \\
\hline \multirow{8}{*}{ cox- } & \multirow{4}{*}{$\begin{array}{l}\text { Adult } \\
\text { Doe }\end{array}$} & \multirow[t]{2}{*}{ Winter } & Control & $0.46 \pm 0.09$ & $1.40 \pm 0.09$ & \multirow[t]{2}{*}{3.71} \\
\hline & & & Treatment & $2.23 \pm 0.25$ & $5.20 \pm 0.83$ & \\
\hline & & \multirow[t]{2}{*}{ Summer } & Control & $0.13 \pm 0.15$ & $1.13 \pm 0.10$ & \multirow[t]{2}{*}{1.79} \\
\hline & & & Treatment & $0.94 \pm 0.18$ & $2.03 \pm 0.25$ & \\
\hline & \multirow{4}{*}{$\begin{array}{l}\text { Goat } \\
\text { Kid }\end{array}$} & \multirow[t]{2}{*}{ Winter } & Control & $0.62 \pm 0.13$ & $1.59 \pm 0.15$ & \multirow[t]{2}{*}{4.17} \\
\hline & & & Treatment & $2.62 \pm 0.21$ & $6.64 \pm 0.90$ & \\
\hline & & \multirow[t]{2}{*}{ Summer } & Control & $-0.19 \pm 0.36$ & $1.06 \pm 0.22$ & \multirow[t]{2}{*}{3.42} \\
\hline & & & Treatment & $1.73 \pm 0.26$ & $3.63 \pm 0.48$ & \\
\hline
\end{tabular}




\begin{tabular}{|c|c|c|c|c|c|c|}
\hline Gene & Animal & Season & Group & $\begin{array}{l}\log 2 \text { fold } \\
\log _{2}\left(2^{\wedge} \Delta \Delta c t\right) \\
\text { relative to } \\
\text { day } 0\end{array}$ & $\begin{array}{l}\text { Fold } \\
\text { expression } \\
\text { (2^- } \Delta \Delta c t) \\
\text { relative to } 0 \\
\text { day }\end{array}$ & $\begin{array}{l}\text { Gene expression fold } \\
\text { difference ratio }\end{array}$ \\
\hline \multirow{8}{*}{$\begin{array}{l}\text { CYT- } \\
\text { B }\end{array}$} & \multirow{4}{*}{$\begin{array}{l}\text { Adult } \\
\text { Doe }\end{array}$} & \multirow[t]{2}{*}{ Winter } & Control & $1.12 \pm 0.21$ & $2.35 \pm 0.35$ & \multirow[t]{2}{*}{3.30} \\
\hline & & & Treatment & $2.88 \pm 0.17$ & $7.76 \pm 0.80$ & \\
\hline & & \multirow[t]{2}{*}{ Summer } & Control & $1.04 \pm 0.19$ & $2.19 \pm 0.29$ & \multirow[t]{2}{*}{2.05} \\
\hline & & & Treatment & $2.03 \pm 0.25$ & $4.51 \pm 0.74$ & \\
\hline & \multirow{4}{*}{$\begin{array}{l}\text { Goat } \\
\text { Kid }\end{array}$} & \multirow[t]{2}{*}{ Winter } & Control & $0.78 \pm 0.29$ & $1.98 \pm 0.41$ & \multirow[t]{2}{*}{3.48} \\
\hline & & & Treatment & $2.72 \pm 0.16$ & $6.90 \pm 0.70$ & \\
\hline & & \multirow[t]{2}{*}{ Summer } & Control & $0.82 \pm 0.29$ & $2.02 \pm 0.35$ & \multirow[t]{2}{*}{2.44} \\
\hline & & & Treatment & $2.20 \pm 0.19$ & $4.94 \pm 0.72$ & \\
\hline
\end{tabular}

HSP-70 gene expression was significantly reduced in M. pruriens supplemented goats. Effect in does was significantly higher in the winter season compared to summer $(P<0.05)$, while in case of goat kids effect was higher in summer season compared to winter season $(P<0.05)$. HSP 90 gene expression was significantly reduced in $M$. pruriens supplemented goats. There was no significant difference found in effect between two seasons in does while in case of goat kids effect was higher in summer season compared to the winter season.

$\log _{2}$ gene expression of mitochondrial function protein COX-I and CYT B were found significantly increased in $M$. pruriens supplemented does and kids during both summer and winter season compared to the control group. Cytochrome oxidase subunit-I (COX-I) gene expression was significantly increased in M. pruriens supplemented goats. There was no significant difference found in effect between two seasons in does \& kids

Cytochrome B (CYT-B) gene expression was significantly increased in M. pruriens supplemented goats. Effect in does was considerably higher in the winter season compared to summer.

Seasonal difference in the extent of gene expression change in $M$. pruriens supplemented group relative to control compared on 30th day.

The extent of log2 relative expression change of tested target gene in $M$ prurien supplemented group relative to control compared on 30th day during winter and summer season has been represented in the Fig. 4. Effect of down-regulation of HSP-70 was found significantly higher during the summer season than winter season in goat kids $(P<0.05)$. Effect on down-regulation of HSP-90 gene expression after $M$. 
pruriens supplementation was found higher during the summer season than winter season $(P<0.05)$ in goat kids. The extent of up-regulation of CYT B gene was significantly greater $(P<0.01)$ in the winter season compared to the summer season in does. Variation between up-regulation of COX-I gene was nonsignificant between two seasons.

\section{Difference between does and kids on the extent of gene expression change in M. pruriens supplemented group relative to control compared on 30 th day.}

The extent of $\log _{2}$ relative expression change of tested target gene in $M$ pruriens supplemented group relative to control group compared on 30th day in adult does, and goat kids have been represented in table no 46 \& graphically represented in Fig. 5. Effect on down-regulation of HSP-70 gene expression after M. pruriens supplementation was found higher in does compare to goat kids during the winter season $(P<0.05)$ while it was higher in goat kids during summer season compared to does $(P<0.05)$. Effect on CYT-B gene up-regulation was found significantly higher in goat kids $(P<0.01)$ compared to does during the summer season. While the extent of HSP -90 up-regulation and COX-I down-regulation were not found significantly different between does and kids.

\section{Discussion}

Heat shock proteins and mitochondrial gene expression levels are two crucial molecular markers of heat stress in animals (Banerjee et al., 2014) reported that; both heat and cold stress-induced the overexpression of HSP-70 genes. Higher expression of HSPs during thermal stress suggests the possible involvement of them to ameliorate the deleterious effect of thermal stress so as to maintain cellular integrity and homeostasis in animals. Higher HSP gene expression has been reported in animals subjected to heat stress. Similarly higher HSP gene expression has been found animals less adapted to the heat stress (Banerjee et al., 2014). Other important molecular change observed in response to heat stress is variation in mitochondrial gene expression. Mitochondrial gene expression levels are important markers of mitochondrial functional status. Bouchama et al. (2017) reported that extreme environmental heat stress in human subjects leads to down-regulation of most of the genes involved in the respiratory chain, including genes encoding the components of complexes I (NADH dehydrogenase-ubiquinone), IV (ubiquinol-cytochrome $\mathrm{c}$ reductase), and V (cytochrome $\mathrm{c}$ oxidase), with a predicted decrease in ATP production, and increase in oxidative stress.

In our study, HSP-70 and HSP-90 gene expression were found to be significantly decreased while COX -I and CYT-B were found significantly increased in $M$. pruriens supplemented does and kids during both summer and winter season compared to the control group. This protective effect was found more pronounced in goat kids, who are normally found more susceptible to summer stress. Previous research work regarding studying the effect of M.pruriens seed supplementation on HSP gene expression during thermal stress in animals are not known. M.pruriens seeds and known to possess antistress and antioxidant properties (Misra and Wagner, 2007). Anti-stress activity is demonstrated by attenuating behavior anomalies exhibited by olfactory bulbectomised rats by chronic M. Pruriens treatment (Pati et 
al., 2010). The main anti-stress and neuroprotective compound identified in $M$. pruriens is L-DOPA. According to Manyam et al. (2004), M. pruriens has a significant neuroprotective effect and restores norepinephrine in the nigrostriatal system and dopamine levels in the substantia nigra of animal models.

M. pruriens seeds have been shown to exhibit neuroprotective effects by an increase in brain mitochondrial complex I activity and significantly restoring dopamine and norepinephrine levels in the parkinsonism animal model (Mundkinajeddu et al., 2021). Phenolics and flavonoids in M. pruriens are antioxidant substances helpful in reducing the risk of oxidative stress-related disorders, including cancer and parkinson's disease (Rai et al., 2015). Induced cerebral ischemia in the wistar rat model resulted in significant neurological damage in the brain of the rats not treated with methanolic extract of M. pruriens seeds as observed in the histopathology of the isolated brain of rats (Nayak et al., 2017). A decrease in HSP gene expression level in our study indicates the amelioration of thermal stress and increase in adaptive response in Beetal goats.

Mitochondria are main site of production of free radicals as well as main targets of free radicals. There is a significant increase in mitochondrial free radical production along with altered mitochondrial protein expression observed during heat stress (Luft \& Landau, 1995). Regarding the effect of M.pruriens on mitochondrial functionality, a study has shown that $M$. pruriens cotyledon powder significantly increased the brain mitochondrial complex-I activity as having NADH and coenzyme Q-10 in the cotyledon powder, which are shown to have a therapeutic benefit in parkinson's disease (Manyam et al.,2014). The diabetic rats supplemented with $M$. pruriens showed a remarkable recovery in antioxidant levels and reduced lipid peroxidation with well-preserved sperm DNA. Mitochondrial membrane potential and mitochondrial function test were also preserved in streptazocin plus $M$ pruriens rat sperm (Suresh et al., 2013). These findings support our results of preserving mitochondrial function by up-regulating respiratory chain component gene expression in M.pruriens supplemented goats. Up-regulation of the mitochondrial genes found in our study indicate improvement in mitochondrial functional status and mitochondrial respiratory efficiency in M.pruriens supplemented beetal goats compared to control goats which are exposed to heat stress. In conclusion, gene expression study results indicated that supplementing M.pruriens seeds @ $100 \mathrm{mg} / \mathrm{kg}$ body weight to goats leads to down-regulation of heat shock response and up-regulation of mitochondrial respiratory chain component gene expression thus having positive impact on adaptive response of Beetal goats against seasonal stress.

\section{Declarations}

Funding - Institutional funding

Conflicts of interest/Competing interests -The authors have no relevant financial or non-financial interests to disclose.

Ethics approval - All the experimental protocols using animals have been approved by the Institutional animal ethical committee (IAEC) of the Guru Angad Dev Veterinary and Animal Sciences University, Ludhiana (Punjab), India, and by CPCSEA, New Delhi vide reference letter V-11011(13)/2/2020-CPCSEA- 
DADF dated 10/02/2020. All the experiments were carried out according to the guidelines of the CPCSEA.

Consent to participate - Not applicable.

Consent for publication - Not applicable.

Informed consent- Not applicable

Availability of data and material - All data are available via the corresponding author.

Code availability - Not applicable.

Authors' contributions- All authors contributed to the study conception and design. Material preparation, data organization, and analysis were performed by Sameer N. Jadhav. The first draft of the manuscript was written by the first author and all authors commented on previous versions of the manuscript. All authors read and approved the final manuscript.

Acknowledgement-Author wants to thank Dean PGs GADVASU for providing necessary facilities for conduction of research work

\section{References}

1. Banerjee, D., Upadhyay, R. C., Chaudhary, U. B., Kumar, R., Singh, S., Polley, S \& De, S. (2014). Seasonal variation in the expression pattern of genes under HSP70. Cell Stress and Chaperones, 19(3), 401-408.

2. Barja, G., \& Herrero, A. (2000). Oxidative damage to mitochondrial DNA is inversely related to maximum life span in the heart and brain of mammals. The FASEB Journal, 14(2), 312-318.

3. Beckham, J. T., Mackanos, M. A., Crooke, C., Takahashi, T., Connell-Rodwell, C., Contag C. H. and Jansen, E. D. (2004). Assessment of cellular response to thermal laser injury through bioluminescence imaging of heat shock protein 70. Photochemistry, Photobiology. 79:76-85.

4. Bernabucci, U., Ronchi, B., Lacetera, N., \& Nardone, A. (2002). Markers of oxidative status in plasma and erythrocytes of transition dairy cows during hot season. Journal of dairy science, 85(9), 21732179.

5. Bouchama, A., Aziz, M. A., Al Mahri, S., Gabere, M. N., Al Dlamy, M., Mohammad, S \& Hussein, M. (2017). A model of exposure to extreme environmental heat uncovers the human transcriptome to heat stress. Scientific reports, 7(1), 1-14.

6. Daromala J, John A and Olusiji S.2015. Effect of Mucuna on spermiogram of west African dwarf buck. Tropical \& Subtropical Agrosystem,1: 192-96.

7. Fung, S. Y., Sim, S. M., Armugam, A., Aguiyi, J. C., \& Tan, N. H. (2014). Prophylactic effect of Mucuna pruriens Linn (velvet bean) seed extract against experimental Naja sputatrix envenomation: gene 
expression studies.

8. Kakkar, P., \& Singh, B. K. (2007). Mitochondria: a hub of redox activities and cellular distress control. Molecular and cellular biochemistry, 305(1), 235-253.

9. Kim, H. G., Kim, T. M., Park, G., Lee, T. H., \& Oh, M. S. (2013). Repeated heat exposure impairs nigrostriatal dopaminergic neurons in mice. Biological and Pharmaceutical Bulletin, b13-00268.

10. Luft, R., and Landau, B. R. (1995). Mitochondrial medicine. Journal of Internal Medicine, 238(5), 405-421.

11. Manyam, B. V., Dhanasekaran, M., \& Hare, T. A. (2004). Neuroprotective effects of the antiparkinson drug Mucuna pruriens. Phytotherapy Research: An International Journal Devoted to Pharmacological and Toxicological Evaluation of Natural Product Derivatives, 18(9), 706-712.

12. Misra, L., \& Wagner, H. (2007). Extraction of bioactive principles from Mucuna pruriens seeds. Indian Journal of Biochemistry \& Biophysics 44, 54-56.

13. Misra, R. P., \& Puneet, K. (2009). Improved shelter management, feeding and watering devices for goats. Goat enterprises, CIRG, Mathura (UP), India, 132.

14. Mundkinajeddu, D., Agarwal, A., Manjunatha, G. G., and Singh, V. K. (2021). Bioactive Constituents in Indian Medicinal Plants Traditionally Recognized for Brain Health Benefits. In Antioxidants and Functional Foods for Neurodegenerative Disorders (pp. 277-327). CRC Press.

15. Nayak, V. S., Kumar, N., D'Souza, A. S., Nayak, S. S., Cheruku, S. P., and Pai, K. S. R. (2017). The effects of Mucuna pruriens extract on histopathological and biochemical features in the rat model of ischemia. Neuroreport, 28(18), 1195-1201.

16. Pati, D., Pandey, D. K., Mahesh, R., Kurdekar, V., and Jhadav, H. R. (2010). Anti-depressant-like activity of Mucuna Pruriens, A traditional Indian herb in rodent models of depression. Phamacology Online, 1, 537-551.

17. Podromou, C., \& Pearl, L. H. (2003). Structure and functional relationships of Hsp90. Current cancer drug targets, 3(5), 301-323.

18. Rai, S. N., Birla, H., Singh, S. S., Zahra, W., Patil, R. R., Jadhav and Singh, S. P. (2017). Mucuna pruriens protects against MPTP intoxicated neuroinflammation in Parkinson's disease through NFKB/pAKT signaling pathways. Frontiers in Aging Neuroscience, 9, 421.

19. Singh, K. M., Singh, S., Ganguly, I., Nachiappan, R. K., Ganguly, A., Venkataramanan, R., ... Narula, H. K. (2017). Association of heat stress protein 90 and 70 gene polymorphism with adaptability traits in Indian sheep (Ovis aries). Cell Stress and Chaperones, 22(5), 675-684.

20. Suresh, S., Prithiviraj, E., Lakshmi, N. V., Ganesh, M. K., Ganesh, L., \& Prakash, S. (2013). Effect of Mucuna pruriens (Linn.) on mitochondrial dysfunction and DNA damage in epididymal sperm of streptozotocin induced diabetic rat. Journal of Ethnopharmacology, 145(1), 32-41.

21. Tucker C B. Rogers A R and Schutz K E 2008. Effect of solar radiation on dairycattle behaviour, use of shade and body temperature in a pasture-based system. Applied Animal Behaviour Science 109: 141-154. 
22. Yakes, F. M., \& Van Houten, B. (1997). Mitochondrial DNA damage is more extensive and persists longer than nuclear DNA damage in human cells following oxidative stress. Proceedings of the National Academy of Sciences, 94(2), 514-519.

\section{Figures}

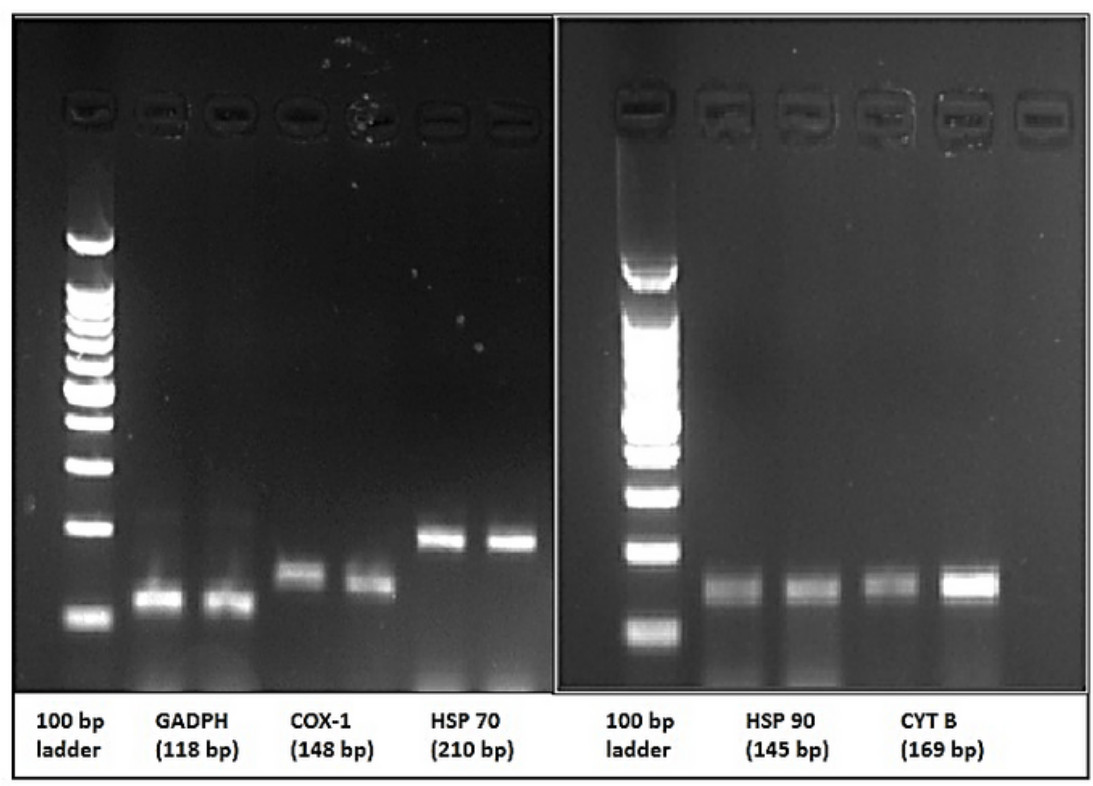

\section{Figure 1}

Confirmation of specific PCR product by agarose gel electrophoresis 

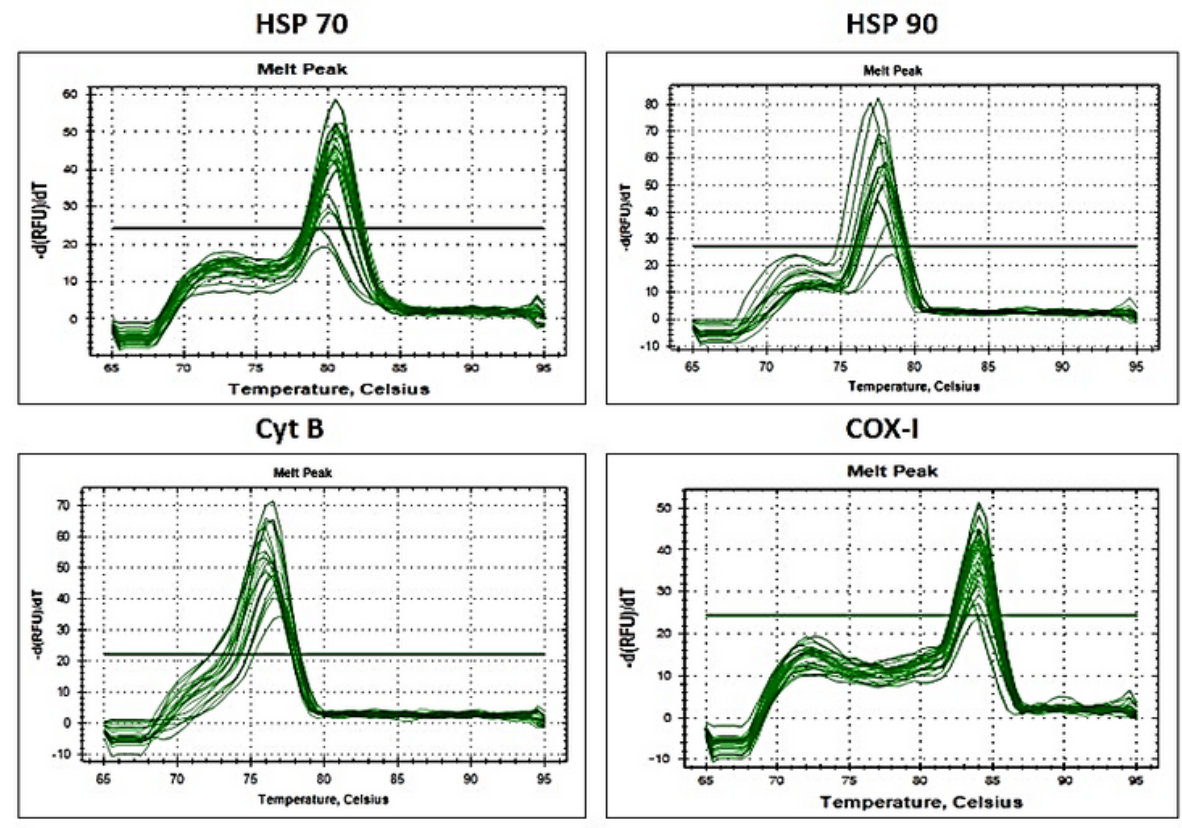

\section{Figure 2}

Melt Curve analysis of specific PCR product amplification of target gene 


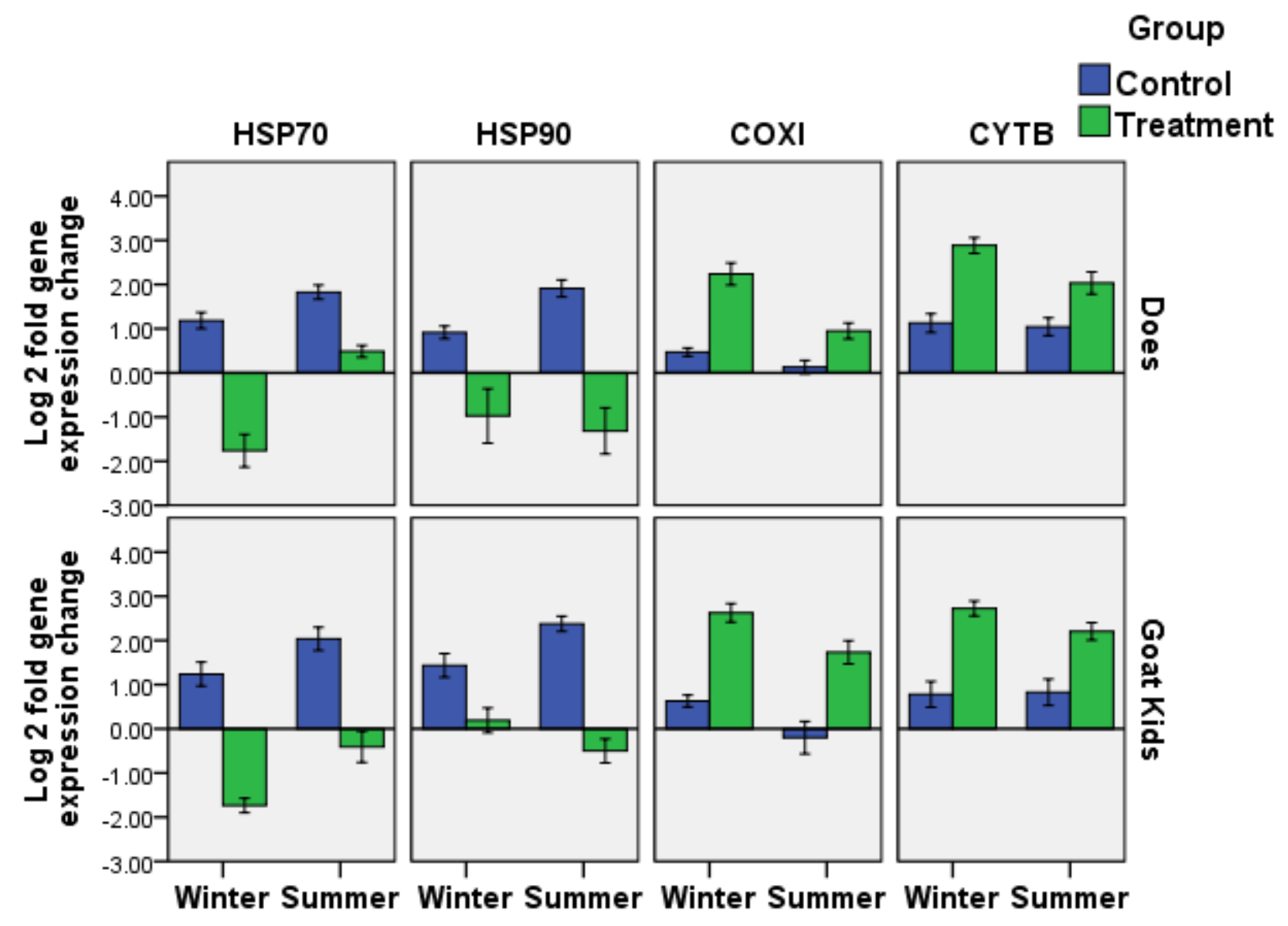

Figure 3

Log 2 Gene expression fold on $30^{\text {th }}$ day (post-feeding) relative to $0^{\text {th }}$ day (prefeeding) 


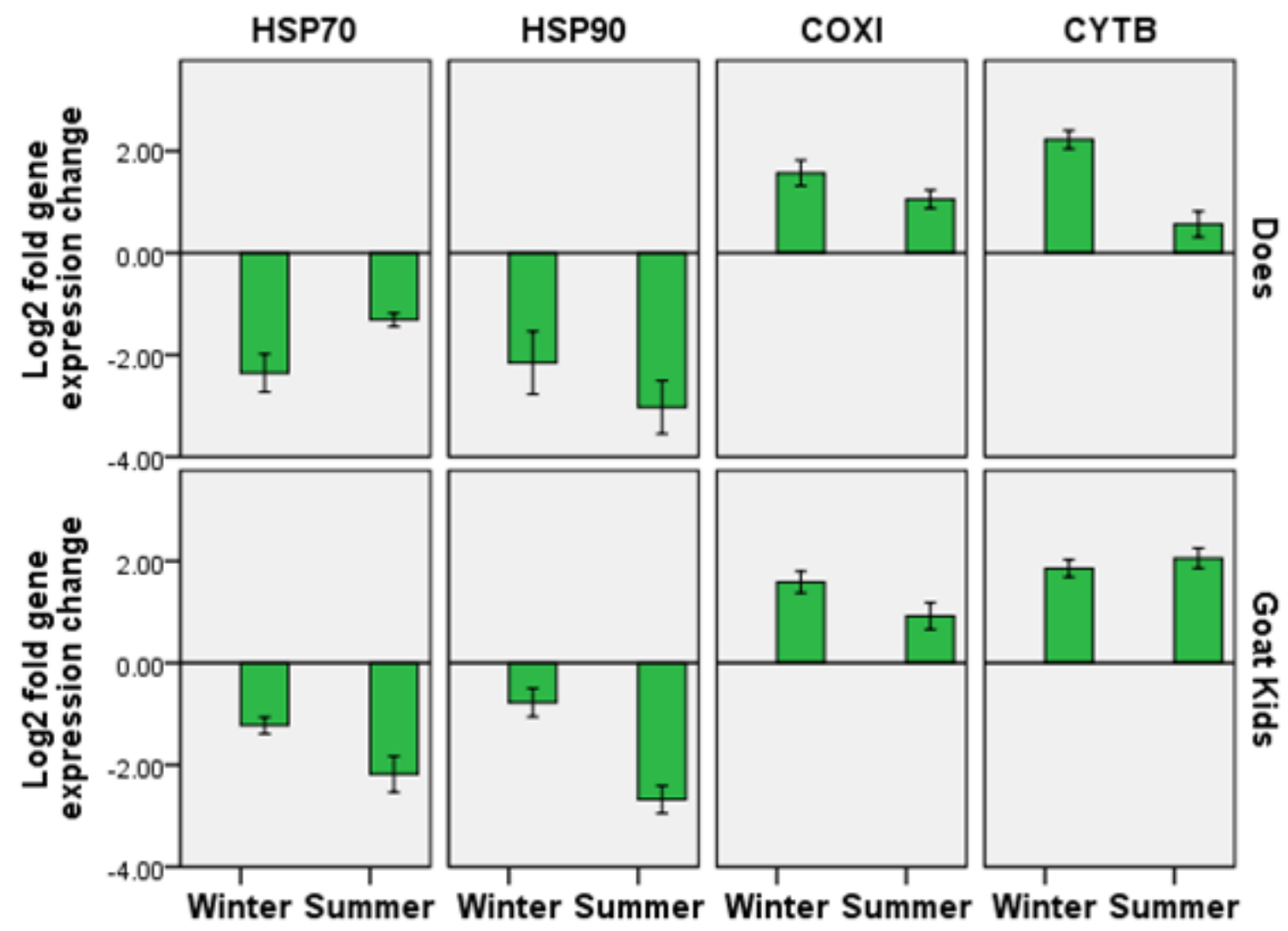

Figure 4

$\log _{2}$ gene expression in $M$ pruriens supplemented group relative to control compared on $30^{\text {th }}$ day during winter and summer season 


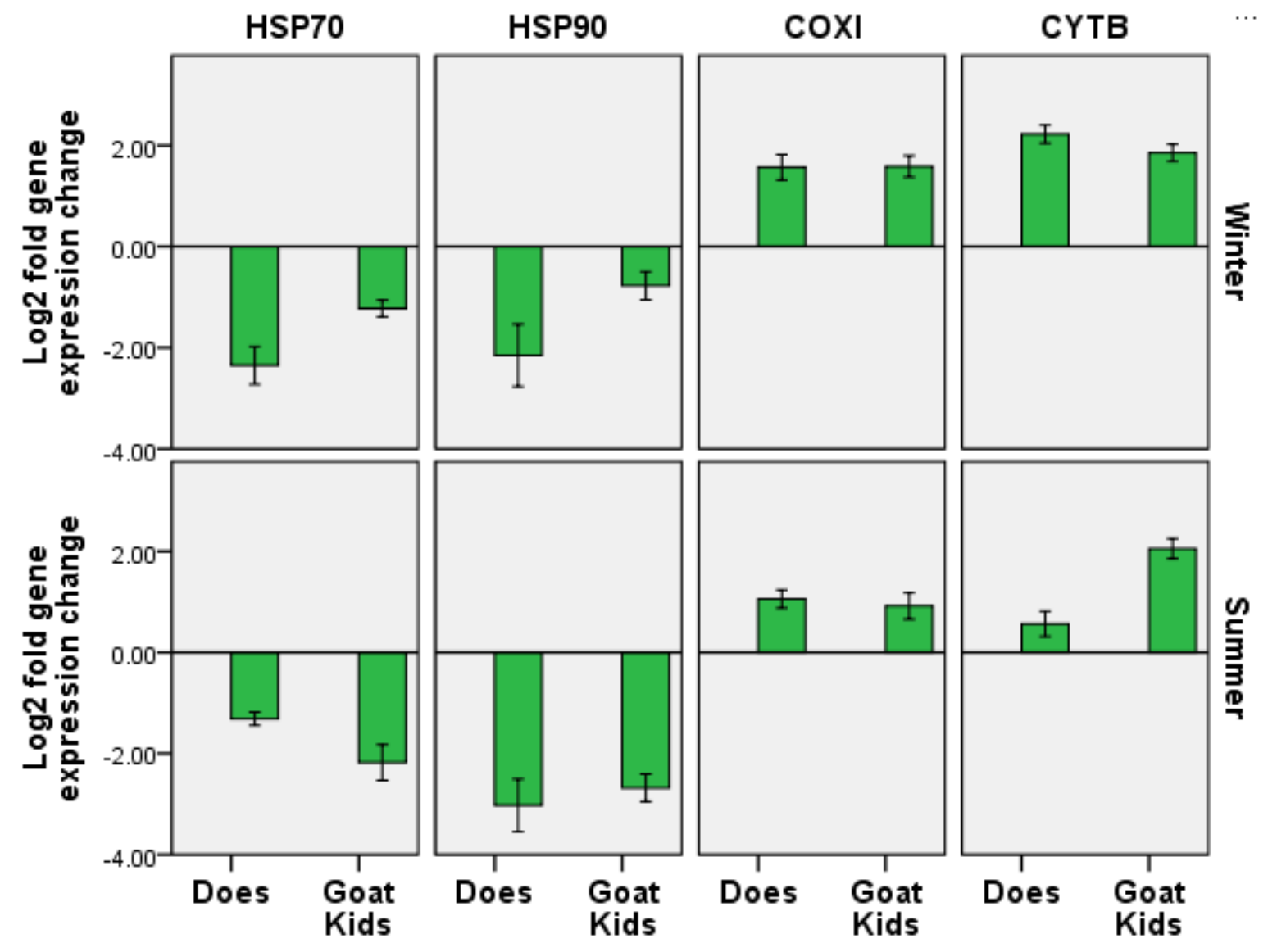

Figure 5

$\log _{2}$ gene expression in $M$. pruriens supplemented group relative to control compared on $30^{\text {th }}$ day in does and goat kids 